\title{
Iran and World Contemporary Developments
}

This conference (www.iranoworld.ir), the first one to be organized by the faculty of the Department of Political Science at Imam Khomeini International University (IKIU) and will be held continuously in the following years, sought to develop knowledge and making the ground suitable for discussing and analyzing the work of researchers both inside and outside Iran.

Despite the antiquity of Iran's history, rich oil and gas resources, and monitoring of the strategic Persian Gulf, the country has enjoyed stability in its blend of religion and politics of social affairs in the face of profound change. Contemporary international relations, known for its dominating principles of equal sovereignty and self-determination, is also undergoing change, the most obvious ones being the Soviet collapse, the "new world order," and globalization, all of which have affected Iran.

Over two hundred abstracts from Iran and abroad (i.e.g, India, Pakistan, Turkey, the United States, Egypt, Algeria, Jordan, Singapore, Australia, Britain, Venezuela, France, South Africa, Russia, Malaysia, Poland, Estonia, Bulgaria, and Burundi) were received; 30 in English and 90 in Persian were approved. Since I cannot cover all of the papers, given space restraints, I will mention the panel titles here and then discuss four of the papers that I found the most interesting: Session 1: Law and Economy Developments; Session 2: Global and Regional Developments; Session 3: Social and Educational Developments; Session 4: Global and Regional Developments; Session 5: Law and Legal Developments; Session 6: Global and Regional Develop- 
ments; Session 7: Energy and Economy Developments; Session 8: Cultural and Social Developments; Session 9: The Islamic Revolution and Iran's Foreign Policy Development; Session 10: Military Strategy Developments; Session 11: The Islamic Revolution and Iran's Foreign Policy Developments; and Session 12: Global and Regional Developments.

Among the most interesting papers for me were the following: Seyed Javad Emamjomehzadeh's and Masumeh Zareie Hodk's (Isfahan University) "Shanghai Cooperation Organization and the Membership of Iran." The presenters detailed the Shanghai Cooperation Organization's (SCO) history, how it is perceived by various experts, and the existence of ongoing talks about amending its mission statement to include, among other things, increased military cooperation, intelligence sharing, and counterterrorism drills. An observer since 2005, Iran requested full membership in March 2008. Emamjomehzadeh sees this as a way for Iran to tighten its contacts with Russia. Experts also says that Iran considers the SCO to be a club of like-minded states that is important to its geostrategic interests in Central Asia.

Abdelkader Nouibat's (University of M'Sila, Algeria) "Development Strategies in Iran and Algeria: A Comparative Study," begins from the assumptions that the state, which plays a major economic and social developmental role in both countries, as well as both countries' reliance upon the petrochemical sector to generate growth and development, would lead one to assume that the results of these strategies would be similar in terms of economic and social development. Using the new comparative economics approach (NCE), Nouibat revealed that the similarities and differences in the two countries' development strategies and their results can be explained by the state's management of economic and social affairs and/or the similarity in their resources endowments, as well as by the changes in their development strategies along with the type and seriousness of internal and external economic and political constraints and pressures.

Muhittin Ataman's (Abant Izzet Baysal University, Turkey, ) "Different Paradigms: The Nation-State System and Islam," asserted that intensified globalization has weakened the Westphalian notion of the nation-state system as a universal political unit. Actually, this has never been true in the nonwestern world. In the wake of the cold war and Huntington's infamous "clash of civilizations" thesis, the Muslim world emerged as the West's "other" because both civilizations have different political, economic, and cultural paradigms. Ataman stressed that since the concepts of nation and nationalism are alien to Islam and Muslims, their expansion within the Mus- 
lim world has caused an identity crisis. Nationalism caused cultural insecurity and has been one of the main bases of Islamic revivalist movements against the West. Therefore, a conceptual evaluation of the nation-state system, ethnicity, and the Islamic approach to politics is required to understand relations between the West and the Muslim world.

Nauman Asghar (Punjab University, Lahore, Pakistan) addressed the "Dimensions of the Arab-Israeli Conflict." Conventional wisdom states that human history is no more than the succession of human and social conflicts punctuated by wars and other forms of violence. In his case study of the sixdecade-long Arab-Israeli conflict, which remains a stumbling block to the Middle East peace process, he maintains that in many respects it has become even more complex and intricate. Asghar traced the historical roots of ArabIsraeli conflict, examined the fundamental thorny issues bedeviling the disputants' relations, analyzed the development of several dimensions of conflict (keeping in view the implications of great power influence), and discussed the various peace and other initiatives. He also mentioned how the recent eruption of the Israel-Hamas conflict in Gaza demonstrates the importance of finding an immediate and durable solution to this ongoing problem. Taking the region's unfolding demographic situation into consideration, he highlighted the significance of the two-state solution.

Bahram Navazeni

Professor of Political Science and Conference Secretary Imam Khomeini International University, Qazvin, Iran 